\title{
Usage of building information modeling for sustainable development education
}

\section{Prof. Benjamin Sanchez, Tecnologico de Monterrey}

Benjamin Sanchez is a Professor of Civil and Environmental Engineering at the Tecnológico de Monterrey campus Puebla and a Young Energy Professional (YEP) ascribed to the Energy Council of Canada (ECC). Benjamin's research is focused in the development and implementation of emergent technologies (BIM, CIM, IoT, Big Data, Machine learning, LCA, 3D scan to BIM) for increasing the performance of construction building projects in terms of sustainability and Circular Economy. Benjamin has done recent contributions on international journals for the valuation and monetization of the environmental impacts of the residual life of building stock in North America. His contributions add a Life Cycle Assessment (LCA) perspective to the decision-making methodology involved in adaptive reuse of buildings, in order to contribute to sustainability and climate change through mitigation of $\mathrm{CO} 2$ emissions.

Benjamin is a Civil Engineer with a doctorate in Civil Engineering from the University of Waterloo in Ontario, Canada. He is originally from the city of Puebla in Mexico. Before initiating his doctoral studies, he worked as infrastructure construction supervisor and environmental inspector of the State of Puebla. Puebla is the fourth largest state in Mexico with 6.1 million inhabitants. Some of his duties were verifying the fulfillment of the applicable laws inside of the construction and environmental jurisdiction for new and existing buildings. Benjamin has been active in the promotion and dissemination of his research work in important forums, through participating in international research academic experiences at Chalmers University in Sweden and ETH Zürich in Switzerland. Also, he has presented his original work in international conferences (ISARC, CIB WBC, CSCE, ASCE, NHICE), and he has collaborated in projects with international organizations such as the Energy Council of Canada (ECC), the Federation of Canadian Municipalities (FCM), and the United Nations Climate Change Conference COP23.

\section{Prof. Romeo Ballinas-Gonzalez, Tecnologico de Monterrey (ITESM)}

Civil Engineer and Master in Project Management from Tecnológico de Monterrey. He did doctoral studies at the Polytechnic University of Catalonia. He is currently a full-time professor at the Tecnológico de Monterrey Campus Puebla since 2013. Founding Partner of the DROEN Ingeniería design firm. He teaches courses in hydrology, hydraulic works, water distribution networks and drainage, sustainable use of water and geomatics at the Tec Campus Puebla.

\section{Prof. Miguel X. Rodriguez-Paz, Tecnologico de Monterrey (ITESM)}

Prof. Rodríguez-Paz got his B.Sc. In Civil Engineering from Tecnologico de Oaxaca in 1993. He studied a M.Sc. In Structural Engineering at Tecnologico de Monterrey and got his Ph.D. from the University of Wales at Swansea in 2003 where he did research on Numerical Methods for Fluid Dynamics as a post-doc Research Officer. In August 2004 he joined Tecnologico de Monterrey at its Puebla Campus. He is a full professor of Applied Mechanics since 2009. His research topics include Engineering Education, Structural Dynamics and Applied Mechanics. He has been a member of the National System of Researchers (SNI) in the Mexican Council of Science and Technology. He has held several position within the School of Engineering, including Head of School and his current post as head of the department of Sustainable Technologies and Civil Engineering. He enjoys teaching Engineering in a fun way and likes to learn about Flipped Learning and Open Education. Since 2010 he is an Academic/educatational Youtuber.

\section{Prof. Juan Arturo Nolazco-Flores, Tecnologico de Monterrey}

Dr. Nolazco holds a BSC. from the Tec of Monterrey, México, and a M.Phil. and Ph.D. from the University de Cambridge, England. He is member of the Mexican Academy of Science, Mexican Academy of Engineering, Mexican Research System, "IEEE Senior Member" and "ACM Senior Member". He is certified by ABET to evaluate academic programs, and he as part of the committe to evaluate the University of West Florida and Grand Canyon University, Arizona. He also was awarded in 2005 and 2009 the 
ITESM Teaching and Research award. As researcher, he has published more than 50 papers, with more than 250 scopus cites (H scopus of 9).

He has been invited as research scholar at Marburg University and Mannheim University, Germany; Carnegie Mellon University, USA; Zaragoza University, Spain; and Cambridge University, England. 


\title{
Usage of building information modeling for sustainable development education
}

\begin{abstract}
Due to environmental concerns Education for Sustainable Development (ESD) has become an essential part on architecture, engineering and construction (AEC) education programs. Emergent technologies such as Building Information Modeling (BIM) can be used as a powerful didactic method approach to improve learning outcomes in terms of ESD. This paper proposes the use of BIM to enhance sustainable development education through the development of construction projects for community development. In this work, we propose a framework that will provide guidelines to effectively incorporate BIM as a tool for enhancing ESD. First, we reviewed the current state of the art of BIM as a didactic method for construction courses in a university in Mexico. We applied the framework in a group of 21 students. The results showed an improvement of $20 \%$ in students ESD learning outcomes. Moreover, the participants reported a better understanding on sustainable development problems as well as higher commitment to get involved in social development projects.
\end{abstract}

\subsection{Introduction}

Emerging trends on sustainable development and information technology such as Building Information Modelling (BIM) are driving profound transformation within architecture, engineering and construction (AEC) education [1], [2]. Therefore, higher education in construction engineering has been striving on implementing effective strategies to instruct competence on BIM [2] and sustainable development on students [3]. However, these topics are typically taught separately in most of the academic programs on higher education institutions, limiting the learning potential for Education for Sustainable Development (ESD) [4]. BIM can be used as a powerful didactic method approach and an efficient teaching strategy to improve learning outcomes in different matters including ESD. ESD is considered as an integral element of quality education and a key enabler for sustainable development [5], [6]. This paper proposes the use of BIM to enhance sustainable development education through the development of construction projects for community development. This study introduces the integration of BIMbased construction projects, with emphasis on transversal citizenship and sustainable development, into undergraduate construction courses using project-based pedagogy. Transversal citizenship is an academic component of support for educational models in universities with the objective of bringing the students close to experiences that links them to the public life and the development of competencies for citizen engagement [7]. This study investigates the role of BIM in facilitating ESD as well as student learning experience. The work presented in this paper provides the desired pedagogical framework that fosters active student learning engagement for community problem-solving with a sustainable development perspective. The results showed an improvement in student ESD learning outcomes, such as, teamwork, resolving challenges, cultural diversity respect, critical thinking, and sustainability. The participants reported a better understanding of sustainable development problems and a higher commitment to getting involved in social development projects. The research presented the status of BIM as a didactic method for construction courses in a university in Mexico and formulated a framework that will provide guidelines to effectively incorporate BIM as a tool for enhancing ESD. 


\subsection{Background}

During the past two decades the role of ESD in higher education has gained the interest of researchers, academicians, and institutions [5]. According to Longhurst et al. [6] ESD can be defined as "the process of equipping students with the knowledge and understanding, skills and attributes needed to work and live in a way that safeguards environmental, social and economic wellbeing, both in the present and for future generations". Even though, the integration of ESD in higher education is recognised as a priority for a growing number of universities, studies for an effective implementation remains new [3]. The effective integration of ESD on engineering education is critical due to the level of impact that engineering projects has on sustainable development [3]. For example, engineers-in-training will be future leaders and specialised professionals who will hold important positions as decision makers on infrastructure projects in all the industries.

Research in the field of Technology-enhanced learning (TEL) has demonstrated the benefits of utilizing information and communication technologies (ICTs) in learning and teaching [8]. It has been argued that the use of ICTs as didactive tools has the potential of enhancing the learning experience and outcomes by taking advantage of the ICT characteristics of flexibility, accessibility, affordability, and absence of temporal or spatial limitations [8]. In this respect, BIM is considered an ICT instrument that is revolutionizing the AEC industry. BIM is defined by international standards as "shared digital representation of physical and functional characteristics of any built object [...] which forms a reliable basis for decisions" [9]. BIM is a realistic and detailed virtual representation of buildings. BIM is accomplished with objectoriented software and consists of parametric objects representing building components that may have geometric or non-geometric attributes with functional, semantic, or topologic information [9]. For example, functional attributes can be construction time, labor demand, and building cost. Semantic information can be interdependency of elements, hosting components, and incompatibility between objects. Topologic attributes can be universal positioning, coplanarity, and perpendicularity of objects. According to Jalaei [10] BIM is an organizing concept that contributes in the lifecycle of a facility to create and manage building data in a convenient way. BIM offers designers the ability to assess different design alternatives at the conceptual stage of the project, through virtual simulation of the performance of the final product [11]. A BIM model is a powerful, highly organized, and user-friendly graphical interface that brings the users the flexibility to visualize and control multiple characteristics of a building project [12]. Because of these characteristics of BIM, some studies have been developed to demonstrate the benefits of using BIM as a didactic tool to improve the understanding of engineering concepts, more than teaching BIM just as a design software [4].

\subsection{Integrating building information modeling and sustainable buildings design}

From the perspective of the US General Services Administration BIM stands for "the development and uses of a multi-faceted computer software data model to not only document a building design, but to simulate the construction and operation of a new capital facility or a recapitalized (modernized) facility. The resulting Building Information Model is a data-rich, object-based, intelligent, and parametric digital representation of the facility, from which views appropriate to various users' needs can be extracted and analyzed to generate feedback and improvement of the facility design" [13]. Numerous researchers have reported benefits from 
implementing BIM in diverse research fields in construction such as preconstruction, design visualization, construction reviews, design coordination, planning of trades and systems, construction scheduling and sequencing, quantity surveys estimating, prefabrication and modularization, as-built modeling for facilities operations and maintenance, built environments and its processes partly integrating sustainability issues, remote sensing technologies, Life Cycle Assessment (LCA) studies, and rubble management [9], [10]. For all these benefits, the implementation of BIM is becoming a cornerstone of the modern construction market as well as for construction project management.

Currently, a considerable amount of research has been done in the area of integration of BIM and sustainability in construction. Project teams have found that synergies between green building and BIM can help to improve the accomplishment of sustainability goals [14]. This interdisciplinary synergy is well known with the name of "green BIM" or "6D BIM". Researchers are still working to deliver the full potential of green BIM. The objective of green BIM is to efficiently integrate the modeling systems, the specialized tools for sustainability, and the databases needed to perform a realistic simulation. Examples of BIM tools available in the market are Revit ${ }^{\circledR}$, OpenBuildings by Bentley®, Vico®, and ArchiCAD®. In North American market Autodesk Revit ${ }^{\circledR}$ is the most prevalent BIM tool. Speaking of green BIM software, some of the most common modeling systems specialized in energy analysis are Ecotect $囚$, Green Building Studio®, eQuest, EnergyPlus $®$, and Integrated Environmental Solutions $®$. Similarly, some of the most developed software for performing LCA in buildings are SimaPro®, $\mathrm{GaBi} \circledast$, Tally®, Athena Impact Estimator ${ }^{\circledR}$, and NIST BEES ${ }^{\circledR}$. Researchers have pointed out that a unique software package does not exist that can provide all the needed functions at all the stages for a sustainability assessment for buildings [10], [14]. Yet, through interoperability and data exchange between applications it is possible to develop integrated green BIM tools. This is possible due to data models have become the international standard for data exchange in the building industry [10].

\subsection{Building information modeling in higher education}

BIM offers designers the ability to assess different design alternatives at the conceptual stage of the project, through the virtual simulation of the performance of the final product [11]. The potential of BIM tools for construction projects has been proven for the past ten years, for example, for detecting and correcting mistakes at the early stages, aiding in accurately scheduling and sequencing the construction, identifying conflicts, advocating design alternatives, and facilitating the selection of appropriate solutions for complex project [11], [15]. BIM is a modern technology which is embraced by the construction industry globally due to the proven benefits to improve construction projects outcomes [16]. The implementation of BIM has also resulted in the development of new roles for BIM actors, such as, BIM manager, BIM coordinator, and BIM modeler [17]. In consequence, higher education institutions around the world have incorporated BIM in AEC academic programs with the purpose of preparing adequately training engineers. However, the adoption and implementation of these kinds of new technologies in education is considered slow [18]. According to Sharag-Eldin, A. [19], curricular changes in higher education programs take a long time to be assimilated which is an impediment to match the speed at which the construction industry advances. BIM is becoming the construction industry standard; therefore, training in BIM technology and its use within AEC curricula are essential [16]. 


\subsection{The knowledge gap}

This paper proposes the use of BIM to enhance ESD through the development of construction projects for community development. This study introduces the integration of BIM-based construction academic projects, with emphasis on transversal citizenship and sustainable development, into undergraduate construction courses using project-based pedagogy. This study investigates the role of BIM in facilitating sustainable development project design as well as student learning experience.

\subsection{Methodology}

In the first stage, it was necessary to bring to the students the literature concerning 1) green BIM tools, 2) the status of the building industry, and 3) sustainable development. For the purposes of this study, it is assumed that the students had already some knowledge in the topics mentioned. Also, one of the main assumptions is that the project is directed to advanced courses in AEC education programs. Therefore, the literature and workshops gave just a quick review that highlights the most important information according to the approach of the project to develop. In a second stage, the students developed a building project that addresses a social problem and proposes a solution using a transversal citizenship approach. The most important deliverable was a BIM model that proposes an affordable solution. The model includes the analytical assessment which demonstrates the benefits in terms of sustainable development. In the final stage, the evaluation of the quality of the project was judged according to an established rubric. On the other hand, the perception on the use of BIM for ESD was measured through an output survey (satisfaction survey).

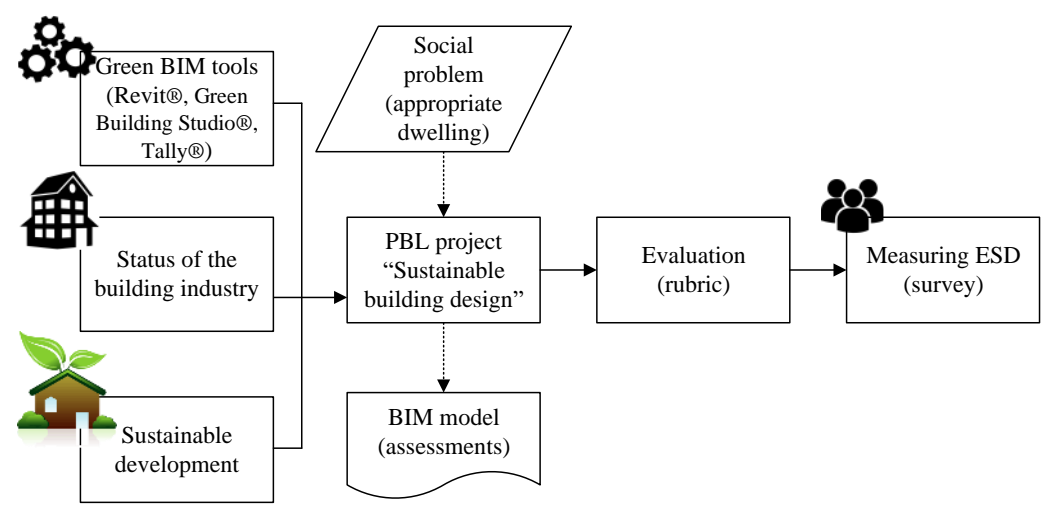

Figure 1: Methodology for using of Building Information Modeling (BIM) to enhance Sustainable Development Education (SDE)

\subsection{Project-based learning approach}

In the last two decades PBL has become an important and recurrent learning technique applied in AEC education in combination with ICTs [1]. PBL is a proven effective pedagogical approach where the students have an active participation in the learning process [20]. PBL involves placing the students in realistic scenarios in order to solve real problematics. Some of the skills the students can develop through this approach are building knowledge, critical thinking, creativity, and soft skills (e.g. leadership, communication, teamwork) [1]. 


\subsection{Transversal citizenship attribute}

Transversal citizenship is an academic component of support for educational models in universities [7]. The objective is to bring the students close to experiences that links them to the public life and the development of competencies for citizen engagement. This academic strategy introduces learning activities for social education with the purpose of fomenting the development of citizen competencies (e.g. leadership, social cost, entrepreneurship). At the same time, this strategy looks for the achievement of the academic objectives of each subject. The transversal citizenship attribute enriches the formation of students by promoting professional development with a civic and democratic basis [21]. For the purposes of this study, the social problem that was introduced to the students was the lack of appropriate dwelling for vulnerable and marginal groups in Mexico. The lack of appropriate dwelling in marginal zones in Mexico has been identified as an important social problem [22]. Some of the focal problems are: 1) lack of appropriate design according to the microclimate of the emplacement, 2) lack of thermal comfort and waste of energy, 3) lack of regulations for energy-efficient building design, and 4) human casualties and toxic effects due to inappropriate practices to warm up the living spaces (e.g. improvised fireplaces inside buildings) [22]. Part of the objectives of the project is to propose alternatives of solution of this problem using sustainable development principles for buildings.

\subsection{Assessment plan}

For the assessment of the quality of the projects it was developed a specific rubric covering the expected content and deliverables, such as, theoretical framework, problem identification, strategies of solution, and conclusions. Table 1 shows a summary of the rubric, including the characteristics of the project, competences to evaluate, and the assigned weight per category. For the assessment of the ESD competencies an exit survey was conducted online at the end of the semester to assess students' knowledge on BIM and their perception for improving their understanding on sustainable development by using BIM. To facilitate future improvement of the course, the exit survey also included open-ended questions regarding their overall course experience and the project. Out of 21 students from one course, all completed the exit survey. According to the survey results, the use of BIM as a platform for the PBL project had a significant positive impact on the understanding of sustainable building design and green building concepts. 
Table 1: Rubric for the assessment of project outcomes

\begin{tabular}{|c|c|c|}
\hline Category & Description & $\begin{array}{c}\text { Sustainable Development } \\
\text { Competences }\end{array}$ \\
\hline $\begin{array}{l}\text { Introduction } \\
(5 \%)\end{array}$ & Brief summary of the project development and results. & \\
\hline $\begin{array}{l}\text { Objective } \\
(5 \%)\end{array}$ & Definition of the general objective, scope and approach. & $\begin{array}{l}\text { Systems thinking, competence to deal } \\
\text { with uncertainty. }\end{array}$ \\
\hline $\begin{array}{l}\text { Background } \\
\text { and } \\
\text { theoretical } \\
\text { framework } \\
(5 \%)\end{array}$ & $\begin{array}{l}\text { 1) Explain the current circumstances of the state of the } \\
\text { need for quality housing in Mexico. 2) Investigate the } \\
\text { legal framework that regulates the design and } \\
\text { construction of housing in Mexico. 3) Description of the } \\
\text { type of housing and location that will be taken as a } \\
\text { reference to propose a design type. 4) Identify the } \\
\text { project stakeholders. }\end{array}$ & $\begin{array}{l}\text { Interdisciplinary learning; planning and } \\
\text { implementation skills; strategic thinking, } \\
\text { action-oriented, and change-agent skills. }\end{array}$ \\
\hline $\begin{array}{l}\text { Problem } \\
\text { identification } \\
(5 \%)\end{array}$ & $\begin{array}{l}\text { State the problem in the context of the project to } \\
\text { develop. }\end{array}$ & $\begin{array}{l}\text { Systems thinking, competence to deal } \\
\text { with uncertainty. }\end{array}$ \\
\hline $\begin{array}{l}\text { Justification } \\
(5 \%)\end{array}$ & $\begin{array}{l}\text { 1) Highlight the importance of the project, 2) } \\
\text { description of the benefits and impacts } 3 \text { ) integrate a } \\
\text { report of pictures. }\end{array}$ & $\begin{array}{l}\text { Participation in shaping sustainable } \\
\text { development processes; cooperative } \\
\text { action and conflict resolution; self- } \\
\text { motivation and motivating others }\end{array}$ \\
\hline $\begin{array}{l}\text { Strategies of } \\
\text { solution and } \\
\text { BIM model } \\
(40 \%)\end{array}$ & $\begin{array}{l}\text { 1) Identify different strategies to solve the causes of the } \\
\text { problem and propose a solution using BIM. 2) Present } \\
\text { the results of some BIM analysis to improve the } \\
\text { performance of the proposed design. The BIM analysis } \\
\text { is of free choice (external insolation, internal radiation, } \\
\text { thermal shooting, LCA). 3) The BIM model has enough } \\
\text { quality at a level of new users. }\end{array}$ & $\begin{array}{l}\text { Understanding of interconnectedness, } \\
\text { and handling of complexity, acting fairly } \\
\text { and ecologically, participation in shaping } \\
\text { sustainable development processes. }\end{array}$ \\
\hline $\begin{array}{l}\text { Conclusions } \\
(20 \%)\end{array}$ & $\begin{array}{l}\text { 1) A conclusion of the project is presented, emphasizing } \\
\text { the positive impacts that the solution design proposal } \\
\text { would have on the quality of life of the community or } \\
\text { communities where it is in the project. 2) Each team } \\
\text { member presents a final reflection where they discuss } \\
\text { the reality of our society in terms of the problems } \\
\text { detected and the intervention that as professionals } \\
\text { through the construction industry, can have to improve } \\
\text { the quality of life of the same. }\end{array}$ & $\begin{array}{l}\text { Long-term, anticipatory, foresighted, and } \\
\text { futures thinking; acting fairly and } \\
\text { ecologically. }\end{array}$ \\
\hline $\begin{array}{l}\text { Bibliography } \\
(5 \%)\end{array}$ & Identify the origin of the data and information. & \\
\hline $\begin{array}{l}\text { Format } \\
(5 \%)\end{array}$ & Present the report in a professional and organized way. & \\
\hline $\begin{array}{l}\text { Teamwork } \\
\text { rubrics } \\
(5 \%)\end{array}$ & $\begin{array}{l}\text { Bring an individual feedback to your team members } \\
\text { about their participation and performance in the } \\
\text { development of the project. }\end{array}$ & Teamwork; resilience. \\
\hline
\end{tabular}

\subsection{Case Study}

The BIM-based PBL activity was implemented in the framework of an engineering course of the civil engineering program. The title of the project was "Design of an ecologic house for vulnerable groups of the population in Mexico". The class was divided in teams from 4 to 5 students. The learning objectives of the activity were established from the beginning:

1) Raising awareness about the lack of dwelling and conditions of life quality in certain sectors of the population in Mexico. 
2) Identifying the problematic of lack of appropriate dwelling in Mexico and the adverse consequences

3) Proposing alternatives of solution through the smart design of a home unit for a specific sector of the population and location.

\subsection{Implementation of the BIM-based PBL activity}

The implementation of the PBL activity is described in the next steps. Step one was the documentation and framework. The students developed a literature review about the current conditions of dwelling in Mexico and the quality of life for vulnerable groups in the society. The problem was identified as well as the consequences in the short, medium, and long term. Step number two was the selection of the geographical location. The students chose the location and context for developing an ecologic dwelling design to solve the need of home units in a specific location in Mexico. The students were encouraged to visit the place to gather data from the location and from the inhabitants. Step number three was the site visit. The students visited the place they chose in the previous stages. The students did interviews with the locals asking for their needs and getting involved with their culture. Step number four was the design of an ecological dwelling using BIM. The students developed a creative, original, and realistic ecologic dwelling design according to investigated information of the emplacement. The final designs were developed using the BIM software Revit ${ }^{\circledR}$. Step number five was the assessment of the proposed dwelling design. The students chose one of the multiple types of assessments that can be performed using the BIM software (e.g. natural lighting analysis, solar radiation analysis, energy balance assessment, LCA). The final dwelling design was tested, and the results were reported. The students documented the process of improving the design by using the BIM assessment. Step number six was the redaction of reflections and conclusions. The students wrote a reflection about the impact of the proposed solution to the problem of lack of appropriate dwelling in Mexico. The reflections and conclusions of each team were shared with the class and discussed. The last step was the project report delivery. The students developed a detailed report of the final proposal. The parts of the report were described in the evaluation rubric of the project.

\subsubsection{Background, theoretical framework and description of the project}

As an example, we present a summary of the parts and structure of one of the projects developed by the students. The project was entitled "Green Chietla". Chietla is a rural community in Mexico located in the state of Puebla. The population is around 30,000 people and the total number of homes is around 9,000. In September $19^{\text {th }}$ of 2017 an unprecedent earthquake of 7.1 Mw with an epicenter in the central part of Mexico affected several communities and cities, including Chietla. The earthquake produced significant damages to buildings and infrastructures. A high percentage of the buildings in Chietla were affected severely producing a humanitarian crisis due to the lack of safe conditions to inhabit the dwellings. For this reason, several social programs were implemented in order to bring the safety back and rebuilt the affected homes. Figure 2 shows an example of evaluation of the damages of a dwelling in Chietla. The evaluation was developed by the students and supervised by professors with knowledge in the field. 

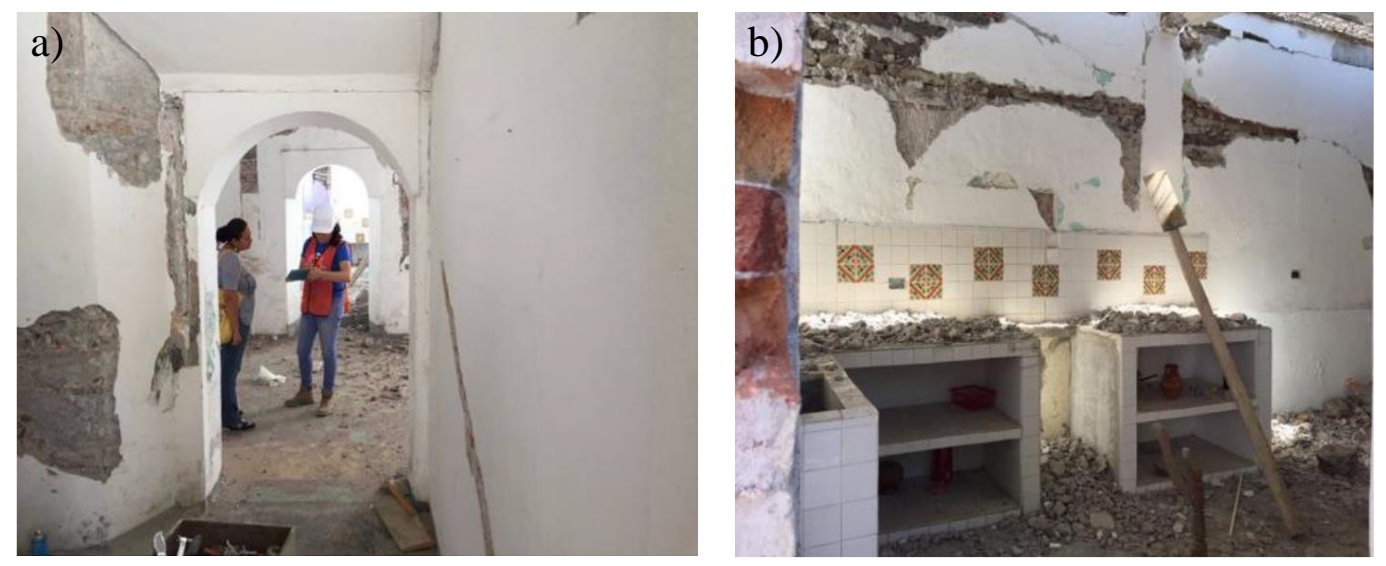

Figure 2: Evaluation of the damages on the dwellings: a) student developing a survey, and b) structural damages on the building.

\subsubsection{Objective of the project}

The objective of this project is to develop a sustainable building design of a residential unit that incorporates the elements of bioclimatic design and it is designed according to the sociocultural characteristics of the community. This project aims to provide a design that implements passive strategies for thermal comfort optimization, such as, sunlight, solar gains, passive cooling.

\subsubsection{Justification}

The elaboration of this project is looking to solve a social need with an alternative that is affordable in terms of sustainable development. The social problem of providing decent homes for the population in vulnerable conditions has become an important need in recent years. In this project, the direct benefit for the environment and the inhabitants is the optimization on resource use, which produces advantages such as, reduction on greenhouses gases production, reduction on the operating cost, increase of the thermal comfort, improvement of the indoor air quality, increase of the durability of the fixed assets, improvement on the daylighting use, decrease on the use of construction materials, and increasing owner's satisfaction.

\subsubsection{Strategies of solution and BIM model}

The BIM software Revit ${ }^{\circledR}$ was used in order to develop the ecologic dwelling design for the municipality of Chietla. For the final design a detailed analysis of indoors natural lighting was developed. It is well known that the appropriate positioning of building openings is fundamental for creating healthy and comfortable indoor environments. Also, an appropriate design can lead to energy savings through the passive heating and cooling of the living spaces. The assessment included the simulation of natural conditions of the emplacement such as, geographical localization, climate of the emplacement, prevailing winds, and existing vegetation. Figure 3 shows the final design as well as some of the simulations of the solar radiation in the facades of the dwelling. 

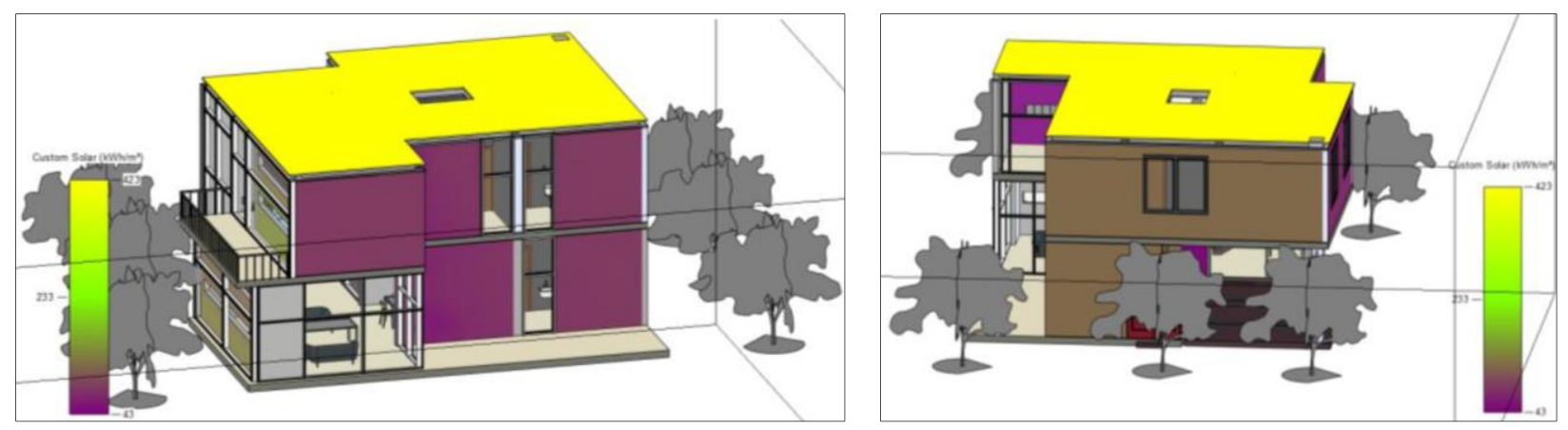

Figure 3: BIM model of the final design of a home unit for the community of Chietla.

\subsection{Assessment of the results and discussion}

The instructor of the course evaluated each of the projects developed by the students. The evaluation was made based in a rubric that was distributed among the students from the beginning of the course. The rubric was intended to measure the development of sustainable development competences in the students as well as the technical quality of the project. The competences for sustainable development to evaluate were Learning to Know (LK), Learning to Do (LD), Learning to live Together (LL), Learning to Be (LB), and Learning to transform oneself and society (LT). Figure 4 shows the student performance distribution. In general, the projects, results, and assessment presented were good, and they had the quality expected for the purposes of the course.

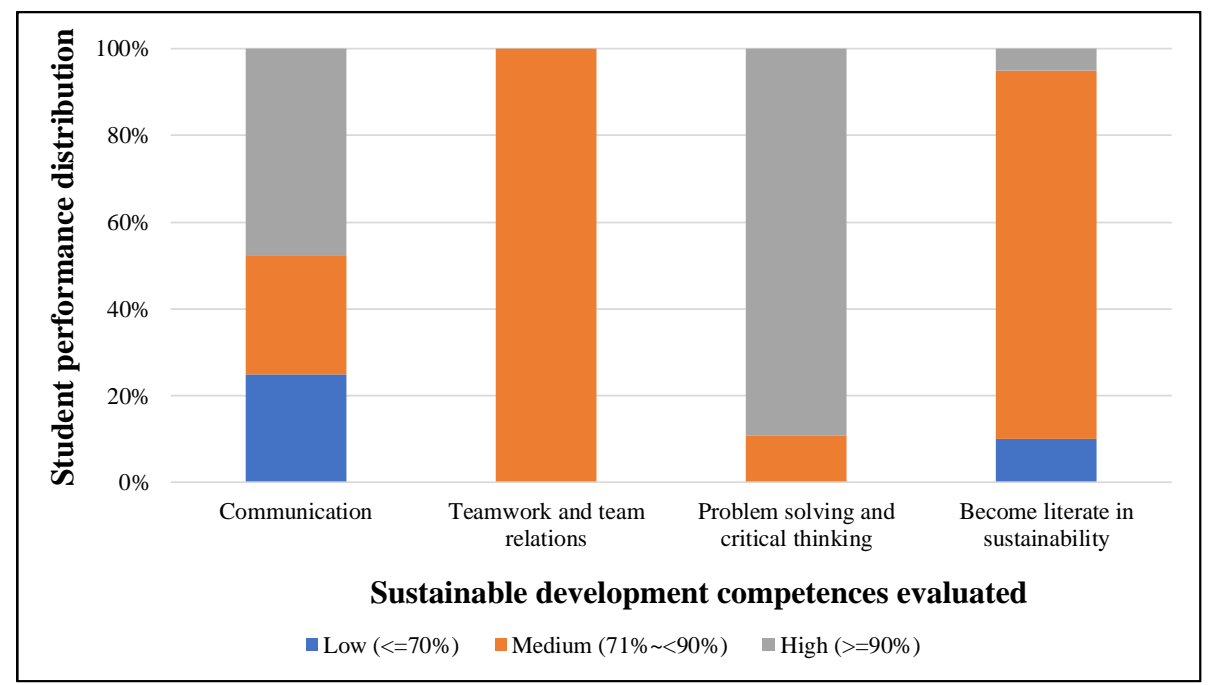

Figure 4: Assessment results of the team projects.

Additionally, an exit survey was conducted online at the end of the semester. The objective was to assess students' knowledge on BIM implementation, green building design strategies, and sustainable development education. All the 21 students of the group completed the exit survey. According to the survey results, the course project had a significant positive impact on students understanding of sustainable development principles. Also, the students found very helpful the use of BIM as a tool to understand the different dimensions of the sustainable building design in 
an applied project. Many students stated that they enjoyed working in teams in a complex project and they were glad to finish the project on time. Additionally, the students pointed out the benefits of using BIM as a powerful design tool and as a pedagogical instrument to understand complex concepts related to sustainable building design. Figure 5 shows the results of the following question: rate the project benefits that you achieved as a result of using BIM for the development of the project. Most of the students agreed that BIM is a powerful design tool, that helped them in understanding better the different dimensions (e.g. architecture, cost, affordability, customised design, design team coordination) that a building project can have.

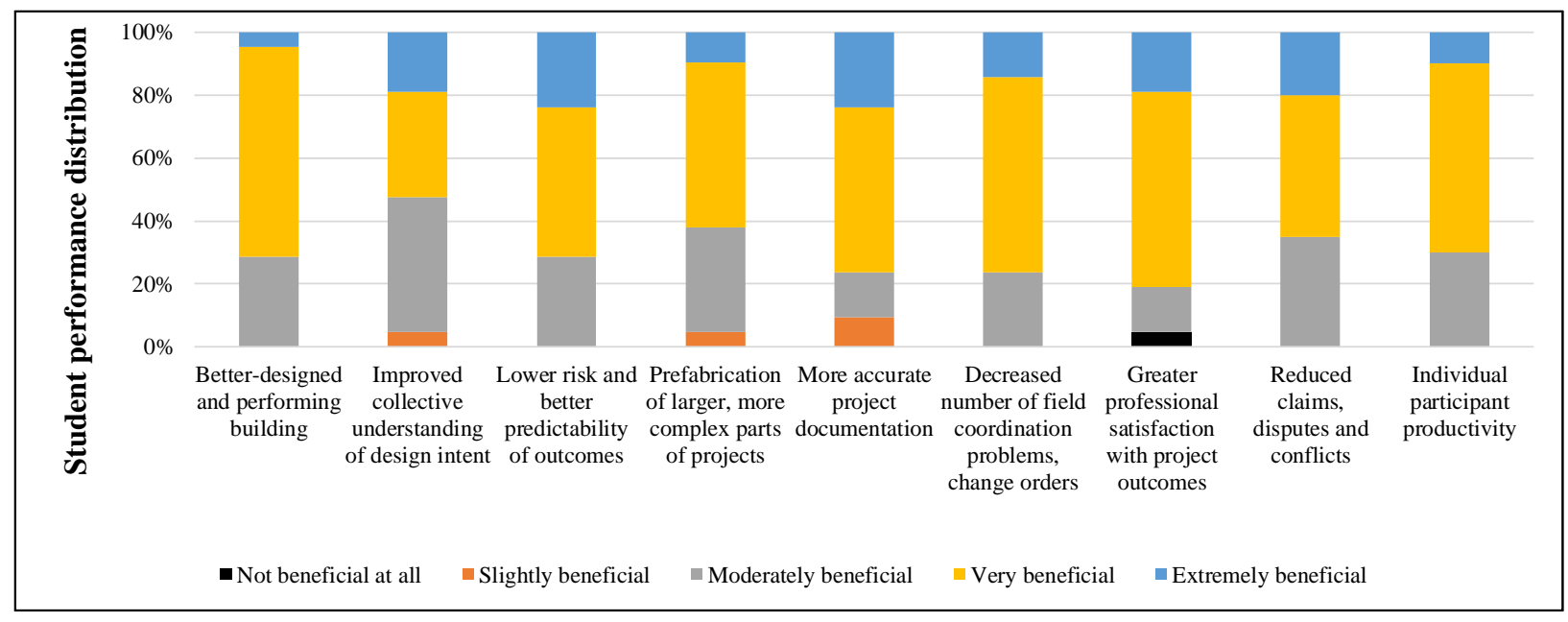

Figure 5: Survey results of the benefits of using BIM in construction projects.

Figure 6 shows the results of the following question: rate the learning outcomes related to sustainable development that you achieved as a result of using BIM in the project. The sustainable development competences evaluated were the following ones:

- Learning to Know (LK) sustainable competences, such as, interdisciplinary learning, system thinking, and understanding interconnectedness.

- Learning to Do (LD) sustainable competences, such as, planning and implementation skills, strategic thinking, and participation in shaping sustainable development processes.

- Learning to live Together (LL) sustainable competences, such as, collaboration in groups, acting fairly and ecologically, and competence to value environment.

- Learning to Be (LB) sustainable competences, such as, change of perspective, selfmotivation and motivating others, and ambiguity and frustration tolerance.

- Learning to transform oneself and society (LT) sustainable competences, such as, communication and use of media, change of perspective, and reflexive competence.

Most of the students agreed that the use of BIM as a didactic tool, improved their understanding of sustainability in a construction project. Also, they agreed that the potential of increasing the development of sustainable competences is considerable. 


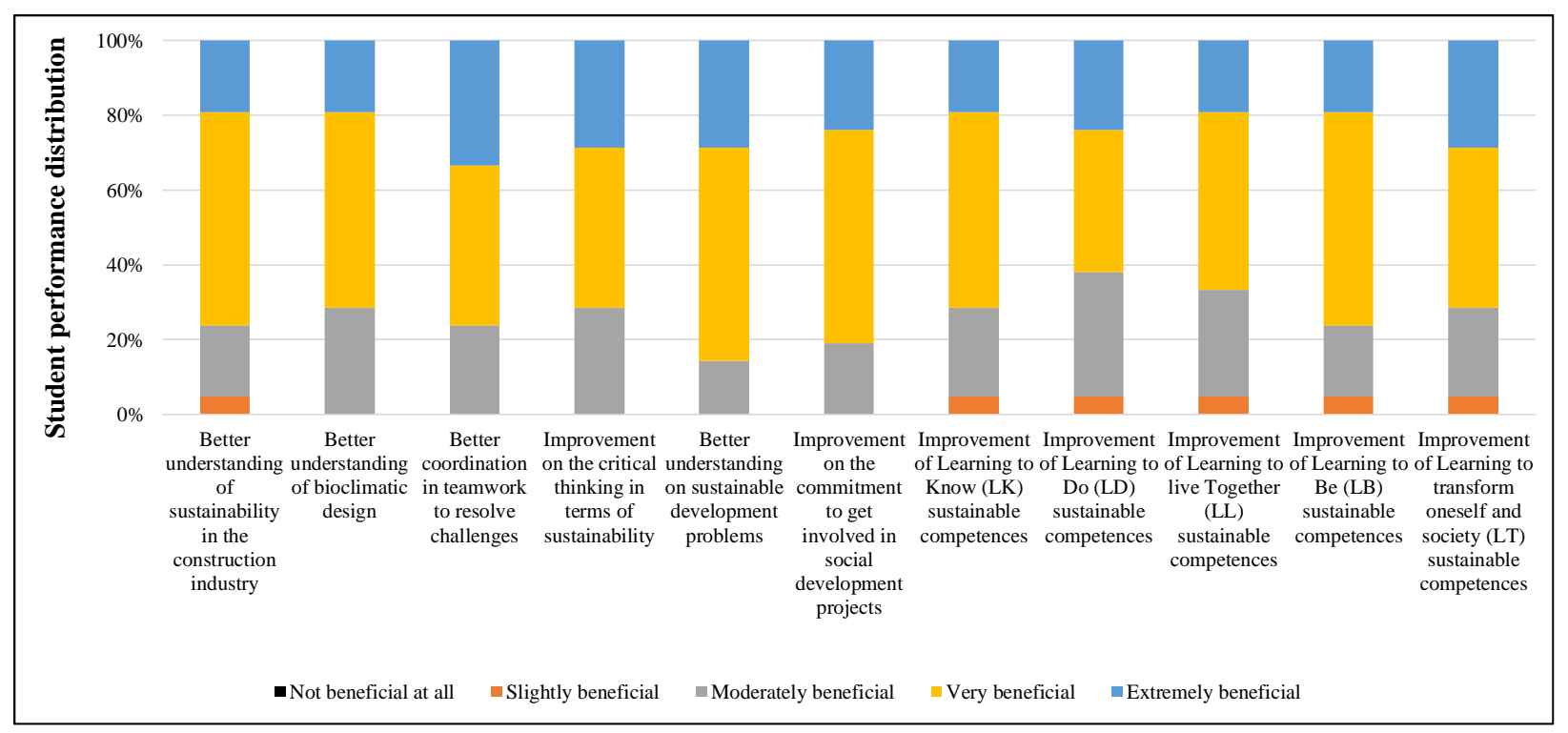

Figure 6: Survey results of the learning outcomes related to education for sustainable development.

\subsection{Conclusions}

This study investigates the role of BIM in facilitating sustainable development project design as well as student learning experience. The work presented in this paper provides the desired pedagogical framework that fosters active students learning engagement for community problem-solving with a sustainable development perspective. The results showed an improvement in students ESD learning outcomes, such as, teamwork, resolving challenges, cultural diversity respect, critical thinking, and sustainability. The participants reported a better understanding on sustainable development problems as well as higher commitment to get involved in social development projects.

In this study it is demonstrated the effectiveness of using BIM as a didactic tool for sustainable building design. In a relatively short period of time ( 2 months) the students were able to develop an entire project with the desired quality. What is more, the students demonstrated understanding and commitment with complex ideas related to sustainability and green buildings. Also, this study demonstrates that the learning experience can be improved using BIM. BIM offers a powerful visual interface with the user that is user-friendly, technically affordable, and realistic. Through the use of BIM, the users can manage a large amount of data embedded in the virtual models (e.g. geometry, cost, schedule, environmental impacts, structural analysis, thermal comfort). All this information is interdependent and correlated to each other and to other external variables. Without a highly advance organizational system like BIM, it would not be possible to develop complex projects as academic activities in order to prepare the students properly for real problems. This study presents the status of BIM as a didactic method for construction courses in a university in Mexico and formulated a framework that will provide guidelines to effectively incorporate BIM as a tool for enhancing ESD. 


\section{Acknowledgement}

The authors would like to acknowledge the financial support of Writing Lab, TecLabs, Tecnologico de Monterrey, Mexico, in the production of this work.

\section{References}

[1] Y. Luo and W. Wu, "Sustainable Design with BIM Facilitation in Project-based Learning," Procedia Engineering, vol. 118, pp. 819-826, 2015. DOI:

https://doi.org/10.1016/j.proeng.2015.08.519.

[2] J. Fridrich and K. Kubečka, "BIM - The Process of Modern Civil Engineering in Higher Education," Procedia - Social and Behavioral Sciences, vol. 141, pp. 763-767, 2014. DOI: https://doi.org/10.1016/j.sbspro.2014.05.134.

[3] A. Pérez-Foguet and B. Lazzarini, "Continuing professional education in engineering faculties: Transversal integration of sustainable human development in basic engineering sciences courses," Journal of Cleaner Production, vol. 218, pp. 772-781, 2019. DOI: https://doi.org/10.1016/j.jclepro.2019.02.054.

[4] A. Abbas, Z. U. Din and R. Farooqui, "Integration of BIM in Construction Management Education: An Overview of Pakistani Engineering Universities," Procedia Engineering, vol. 145, pp. 151-157, 2016. DOI: https://doi.org/10.1016/j.proeng.2016.04.034.

[5] A. Nousheen et al, "Education for sustainable development (ESD): Effects of sustainability education on pre-service teachers' attitude towards sustainable development (SD)," Journal of Cleaner Production, pp. 119537, 2019. DOI: https://doi.org/10.1016/j.jclepro.2019.119537.

[6] J. Longhurst et al, "Education for sustainable development: Guidance for UK higher education providers," 2014.

[7] Instituto Tecnológico y de Estudios Superiores de Monterrey (ITESM). (2019, Dec 15). Modelo educativo TEC 21.

[8] C. Shen and J. Ho, "Technology-enhanced learning in higher education: A bibliometric analysis with latent semantic approach," Computers in Human Behavior, vol. 104, pp. 106177, 2020. DOI: https://doi.org/10.1016/j.chb.2019.106177.

[9] R. Volk, J. Stengel and F. Schultmann, "Building Information Modeling (BIM) for existing buildings - Literature review and future needs," Autom. Constr., vol. 43, pp. 204-204, JUL, 2014.

[10] F. Jalaei, "Integrate Building Information Modeling (BIM) and Sustainable Design at the Conceptual Stage of Building Projects." , University of Ottawa, 2015. 
[11] F. Jalaei and A. Jrade, "An Automated BIM Model to Conceptually Design, Analyze, Simulate, and Assess Sustainable Building Projects," Journal of Construction Engineering, vol. 2014, pp. ID 672896, 2014.

[12] B. Sanchez, C. Rausch and C. Haas, "Deconstruction programming for adaptive reuse of buildings," Autom. Constr., vol. 107, pp. 102921, 2019. DOI:

https://doi.org/10.1016/j.autcon.2019.102921.

[13] US General Services Administration (GSA), "BIM Guide Overview," 2007.

[14] W. Wu and R. R. A. Issa, "An integrated green BIM process model (IGBPM) for BIM execution planning in green building projects," in Building Information Modeling: Applications and Practices, R. R. A. Issa and S. Olbina, Eds. Reston, Virginia, USA: American Society of Civil Engineers (ASCE), 2015, pp. 135.

[15] V. J. L. Gan et al, "Holistic BIM framework for sustainable low carbon design of high-rise buildings," Journal of Cleaner Production, vol. 195, pp. 1091-1104, 2018. DOI: https://doiorg.proxy.lib.uwaterloo.ca/10.1016/j.jclepro.2018.05.272.

[16] B. Y. Yusuf, K. N. Ali and M. R. Embi, "Building Information Modeling as a Process of Systemic Changes for Collaborative Education in Higher Institution," Procedia-Social and Behavioral Sciences, vol. 219, pp. 820-827, 2016.

[17] P. M. Bosch-Sijtsema, P. Gluch and A. A. Sezer, "Professional development of the BIM actor role," Automation in Construction, vol. 97, pp. 44-51, 2019. DOI:

https://doi.org/10.1016/j.autcon.2018.10.024.

[18] C. M. Herr and T. Fischer, "BIM adoption across the Chinese AEC industries: An extended BIM adoption model," Journal of Computational Design and Engineering, vol. 6, (2), pp. 173178, 2019. DOI: https://doi.org/10.1016/j.jcde.2018.06.001.

[19] Sharag-Eldin Adil and Nawari Nawari. O., "BIM in AEC Education," Structures Congress 2010, pp. 1676-1688, 2020/01, 2010.

[20] G. Baş, "Investigating the effects of project-based learning on students' academic achievement and attitudes towards English lesson," The Online Journal of New Horizons in Education, vol. 1, (4), 2011.

[21] E. Adame-Torres, "Valor Percibido Por Estudiantes Del ITESM En El Desarrollo De Competencias Transversales.", Instituto Tecnológico y de Estudios Superiores de Monterrey, 2018.

[22] B. Sanchez et al, "Analysis of an affordable rural ecologic home for marginal communities in the sierra negra zone, state of Puebla, Mexico," in Energy and Environment Nowadays, L. Torres and E. R. Bandala, Eds. New York: Nova publishers, 2015, pp. 207. 